\title{
Production and characterization of cellulolytic enzymes by Pleurotus florida
}

\author{
Meenakshi Goyal* and Giridhar Soni
}

\author{
Department of Biochemistry, Punjab Agricultural University, Ludhiana- 141004, Punjab, India.
}

Accepted 19 April, 2011

\begin{abstract}
Three Pleurotus spp., Pleurotus florida, Pleurotus ostreatus and Pleurotus sajar-caju, were screened for cellulolytic enzyme production under submerged fermentation conditions. Of these, $P$. florida, was studied for optimizing medium composition, incubation period, initial $\mathrm{pH}$ and incubation temperature to maximize cellulolytic enzyme production. Malt extract at $0.5 \%, 12$ day of incubation period and $1 \%$ CMC as carbon source supported maximum production of cellulases. The optimum temperature and $\mathrm{pH}$ for maximum production of enzymes were 35 to $40^{\circ} \mathrm{C}$ and 5.0 for exo-and endoglucanases and $30^{\circ} \mathrm{C}$ and 4.5 for $\beta$ - glucosidase.
\end{abstract}

Key words: Endoglucanase, exoglucanase, fermentation conditions, $\beta$-glucosidase, medium composition.

\section{INTRODUCTION}

Cellulose is the most abundant organic compound on earth and as such has received a greater deal of attention as a substrate for the production of biofuel, single cell protein and a variety of chemicals through enzymatic degradation by microbial cellulases. The conversion of cellulosic biomass to fermentable sugars requires synergistic action of three cellulolytic enzymes namely $\beta-1,4$ endoglucanase (EC 3.4.1.4), $\beta-1,4$ exoglucanase (EC 3.2.1.91) and $\beta-1,4$ glucosidase (EC 3.2.1.21). Several microorganisms like bacteria, fungi and yeast have been reported to synthesize these enzymes. The most extensively studied cellulases are those produced by efficient lignocellulose degrading fungi, particularly Trichoderma (Narsimha et al., 2006) and Aspergillus spp. (Baig, 2005). Mushrooms can be exploited as an alternative and safe source of extracellular cellulolytic enzymes. Of these, Pleurotus spp are most efficient in utilizing lignocellulosics (Zhang et al., 2002; Salmones et al., 2005; Albores et al., 2006). We therefore first screened three Pleurotus spp namely Pleurotus florida, Pleurotus ostreatus and Pleurotus sajar-caju for cellulolytic enzymes production and studied in details $P$. florida for various cultural and nutritional

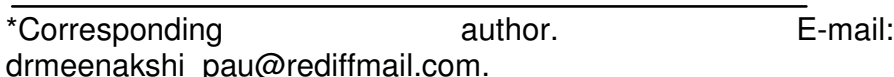

parameters for enhanced production of extracellular cellulases using submerged fermentation conditions.

\section{MATERIALS AND METHODS}

The three Pleurotus spp. procured from Department of Microbiology, Punjab Agricultural University, Ludhiana, were screened for production of cellulolytic enzymes by growing them on Czapek Dox medium at $35^{\circ} \mathrm{C}$ for 12 days with an initial $\mathrm{pH}$ of 5.0 containing $1 \% \mathrm{CMC}$ as carbon source. Based upon the activities of all the three components of the cellulases (Table 1), $P$. florida was found to be the best producer of these enzymes and was selected for further study. The strain was maintained and sub cultured fortnightly on potato dextrose agar (PDA) slants and stored at $4^{\circ} \mathrm{C}$.

Czapek Dox medium used for enzyme production by $P$. florida to ferment CMC comprised $\left(\mathrm{gl}^{-1}\right)$ : carboxyl methyl cellulose 10-30, $\mathrm{Na}_{2} \mathrm{HPO}_{4}$ 1.0, $\mathrm{NaNO}_{3} \quad 3.0, \quad \mathrm{KCl} \quad 0.5, \quad \mathrm{MgSO}_{4} .7 \mathrm{H}_{2} \mathrm{O} \quad 0.1$ and $\mathrm{FeSO}_{4} .7 \mathrm{H}_{2} \mathrm{O} 0.001$ in the absence or presence of 0.1 to $1 \%$ malt extract. Cotton plugged $250 \mathrm{ml}$ Erlenmeyer flasks containing $50 \mathrm{ml}$ medium were autoclaved at $121^{\circ} \mathrm{C}$ for $30 \mathrm{~min}$, cooled to room temperature and inoculated with $1 \mathrm{~mm}$ disks from the growing edge of culture. The flasks were incubated at $30^{\circ} \mathrm{C}$ for 15 days under stationary conditions and three flasks were drawn at each 5 day interval for enzymatic determinations in culture media.

Activities of glucanases were assayed according to the methods described by Mandels et al. (1976). For endoglucanases activity, the reaction mixture, consisting of $1.0 \mathrm{ml}$ of $0.05 \mathrm{M}$ citrate buffer $(\mathrm{pH}$ $-4.8), 1.0 \mathrm{ml}$ of $1 \% \mathrm{CMC}$ solution and $0.5 \mathrm{ml}$ of culture filtrate, was incubated at $50^{\circ} \mathrm{C}$. Samples $(0.5 \mathrm{ml})$ were drawn at 0 and $30 \mathrm{~min}$ of incubation period for determination of reducing sugars released using dinitrosalicylic acid (DNS) method (Miller, 1959). Likewise the 
Table 1. Production of cellulases by Pleurotus spp. in Czapek medium.

\begin{tabular}{lccc}
\hline \multirow{2}{*}{ Organism } & \multicolumn{3}{c}{ Enzyme activity (IUL ${ }^{-1}$ ) } \\
\cline { 2 - 4 } & Endoglucanase & Exoglucanase & $\beta$-glucosidase \\
\hline P. ostreaus & 420 & 82 & 880 \\
P. florida & 480 & 102 & 980 \\
P. sajarcaju & 450 & 54 & 856 \\
\hline
\end{tabular}

exoglucanase activity was determined by using $6 \times 1 \mathrm{~cm}$ Whatman no. 1 filter paper strips, cut into small pieces. The cut strips were incubated with $2 \mathrm{ml}$ of $0.05 \mathrm{M}$ citrate buffer containing $0.5 \mathrm{ml}$ culture filtrate at $50^{\circ} \mathrm{C}$ and the reducing sugars released, were determined at 0 and 60 min intervals by DNS method (Miller, 1959). For $\beta$ glucosidase activity, the reaction mixture, consisting of $1 \mathrm{ml}$ of $1 \%$ cellobiose solution, $0.5 \mathrm{ml}$ of $0.05 \mathrm{M}$ citrate buffer $(\mathrm{pH}-4.8)$ and 0.5 $\mathrm{ml}$ of enzyme, was incubated at $50^{\circ} \mathrm{C}$. Reducing sugars released were measured at 0 and 15 min of incubation period using DNS method. The enzymatic activities were expressed as international units $\left(\mathrm{IUL}^{-1}\right)$. One unit of enzyme was defined as the amount of enzyme that released one micromole of reducing sugars per minute under the assay conditions. Culture conditions were optimized for production of cellulases by $P$. florida with respect to medium constituents, incubation period, incubation temperature, medium $\mathrm{pH}$ and concentration of carbon source. The cellulolytic enzymes produced were also characterized for their optimum $\mathrm{pH}$, optimum temperature and thermostability.

\section{RESULTS AND DISCUSSION}

\section{Optimization of medium ingredients}

$P$. florida was grown on Czapek Dox medium containing $1 \% \mathrm{CMC}$ in the presence or absence of malt extract. It was found that different enzymes peaked at different fermentation period and declined subsequently which could be due to the inactivation and or degradation of these enzymes (Mandels and Stenberg, 1976). Activities of all these enzymes were poor in the absence of malt extract and were maximum with $0.5 \%$ malt extract. Maximum production of endoglucanase $\left(460 \mathrm{IUL}^{-1}\right)$ and exoglucanase $\left(105 \mathrm{IUL}^{-1}\right)$ with $0.5 \%$ malt extract was obtained on 12th day of the fermentation period (Tables 2). Previous reports showed a peak after 8 days of incubation period for cellulase enzyme activity by using $0.5 \%$ malt extract for P.ostreatus (Platt et al., 1984) and Volvariella (Phutela et al., 1996) strains. However, with $1.0 \%$ malt extract concentration, an early peak at 5 and 7th day of incubation period was achieved for endoglucanase (341 IUL ${ }^{-1}$ ) and exoglucanase $\left(85 \mathrm{IUL}^{-1}\right)$ respectively but the production was low as compared to that obtained with $0.5 \%$ malt extract on $12^{\text {th }}$ day. With lower concentrations of malt extract (0.1\%), comparatively low levels of cellulolytic enzymes were produced with maxima on 15th day of incubation period. $\beta$-glucosidase showed maximum production with $1 \%$ malt extract $\left(1066 \mathrm{IUL}^{-1}\right)$ on 5 th day whereas with $0.5 \%$ malt extract medium, a slightly low production $\left(1040 \mathrm{IUL}^{-1}\right)$ was achieved on 12th day of incubation. Thus increasing malt extract concentration in production medium can shorten incubation period for maximum cellulases production. Since maximum endo- and exoglucanase can only be obtained with $0.5 \%$ malt extract, so this concentration was chosen for further experiments.

When cellulose (1\%) was used as carbon source in production medium, very poor response with respect to endo- and exoglucanases production was observed. Supplementation of production media with malt extract (0.5 or $1 \%$ ) concentrations, however, improved the cellulolytic enzymes production (Table 2). Maximum production of endo- and exoglucanases was achieved with $1 \%$ malt extract, which peaked between 7 to 10 th day of incubation period for endoglucanase $\left(213 \mathrm{IUL}^{-1}\right)$ and at 12 th day for exoglucanase $\left(46 \mathrm{IUL}^{-1}\right)$. For $\beta$-glucosidase, also maximum activity was achieved with $1 \%$ malt extract concentration level at 7 th day of incubation period (854 $I U L^{-1}$ ) (Table 2). With wheat straw as an alternative carbon sources, maximum endoglucanse $\left(235 \mathrm{IUL}^{-1}\right)$, exoglucanase (152 IUL ${ }^{-1}$ ) and $\beta$ - glucosidase $\left(1025 \mathrm{IUL}^{-1}\right)$ production was achieved on 7,10 and 7th day of incubation period respectively using $1 \%$ malt extract (Table 2). Tan and Wahab (1997) detected higher cellulolytic enzymes production from $P$. sajar caju by using treated cotton waste as compared to normal cotton in culture filtration. However, other workers used cottonwheat straw mixture for inducing lignocellulytic activity of $P$. pulinonarius in liquid culture (Masaphy and Levanon, 1992).

Of all the carbon sources used, CMC gave a better enzyme production. Moreover maximum production of glucanases was achieved with $0.5 \%$ malt extract, so for further enzyme production improvement, culture conditions were optimized with respect to incubation period, temperature and level of carbon source.

\section{Effect of incubation temperature}

Effect of incubation temperature on cellulolytic enzyme production was studied by growing $P$. florida at different temperatures (Table 3). It was found that growth of fungus did not correlate with the production of enzymes. The optimum temperature for endoglucanase and exoglucanase production was found to be between 35 to $40^{\circ} \mathrm{C}$. But maximum biomass production was obtained at 
Table 2. Effect of supplementation of Czapek medium with different carbon sources (1\%) and malt extract concentrations $(0$, $0.1,0.5$ and $1.0 \%$ ) on cellulase activity at different days of incubation period by $P$. florida.

\begin{tabular}{|c|c|c|c|c|c|}
\hline \multirow{2}{*}{ Carbon source (1\%) } & \multirow{2}{*}{ Incubation period } & \multicolumn{4}{|c|}{ Malt extract concentration (\%) } \\
\hline & & 0 & 0.1 & 0.5 & 1.0 \\
\hline \multirow[t]{18}{*}{ CMC } & & \multicolumn{4}{|c|}{ Endoglucanase $\left(\mathrm{UL}^{-1}\right)$} \\
\hline & 5 & ND & 213 & 234 & 340 \\
\hline & 7 & 166 & 320 & 320 & 170 \\
\hline & 10 & 102 & 313 & 356 & 192 \\
\hline & 12 & 21 & 277 & 460 & 252 \\
\hline & \multirow[t]{2}{*}{15} & ND & 384 & 296 & 106 \\
\hline & & \multicolumn{4}{|c|}{ Exoglucanase $\left(\mathrm{UL}^{-1}\right)$} \\
\hline & 5 & ND & ND & 8 & 65 \\
\hline & 7 & 10 & 16 & 25 & 85 \\
\hline & 10 & 5 & 42 & 82 & 72 \\
\hline & 12 & 40 & 64 & 105 & 64 \\
\hline & \multirow[t]{2}{*}{15} & 64 & 88 & 41 & 35 \\
\hline & & \multicolumn{4}{|c|}{$\beta$-glucosidase $\left(\mathrm{UL}^{-1}\right)$} \\
\hline & 5 & 50 & 504 & 746 & 1066 \\
\hline & 7 & 304 & 612 & 720 & 950 \\
\hline & 10 & 262 & 612 & 840 & 842 \\
\hline & 12 & 201 & 604 & 1040 & 822 \\
\hline & 15 & 71 & 752 & 123 & 213 \\
\hline \multirow[t]{18}{*}{ Cellulose } & & \multicolumn{4}{|c|}{ Endoglucanase $\left(\mathrm{UL}^{-1}\right)$} \\
\hline & 5 & ND & 2 & 114 & 146 \\
\hline & 7 & 3 & 2 & 106 & 213 \\
\hline & 10 & 3 & 3 & 136 & 210 \\
\hline & 12 & 2 & 4 & 149 & 140 \\
\hline & \multirow[t]{2}{*}{15} & ND & ND & 128 & 28 \\
\hline & & \multicolumn{4}{|c|}{ Exoglucanase $\left(\mathrm{UL}^{-1}\right)$} \\
\hline & 5 & ND & ND & 5 & 8 \\
\hline & 7 & ND & 1 & 9 & 8 \\
\hline & 10 & ND & 1 & 13 & 40 \\
\hline & 12 & ND & 4 & 15 & 46 \\
\hline & \multirow[t]{2}{*}{15} & ND & 5 & 40 & 24 \\
\hline & & \multicolumn{4}{|c|}{$\beta$-glucosidase $\left(\mathrm{UL}^{-1}\right)$} \\
\hline & 5 & ND & 201 & 322 & 712 \\
\hline & 7 & ND & 310 & 452 & 854 \\
\hline & 10 & 102 & 217 & 700 & 605 \\
\hline & 12 & 200 & 380 & 711 & 610 \\
\hline & 15 & 210 & 440 & 422 & 151 \\
\hline \multirow[t]{6}{*}{ Wheat straw } & & \multicolumn{4}{|c|}{ Endoglucanase $\left(\mathrm{UL}^{-1}\right)$} \\
\hline & 5 & ND & 54 & 87 & 182 \\
\hline & 7 & 4 & 50 & 107 & 235 \\
\hline & 10 & 4 & 60 & 120 & 149 \\
\hline & 12 & 3 & 64 & 128 & 150 \\
\hline & 15 & ND & 106 & 115 & 150 \\
\hline
\end{tabular}


Table 2. Contd.

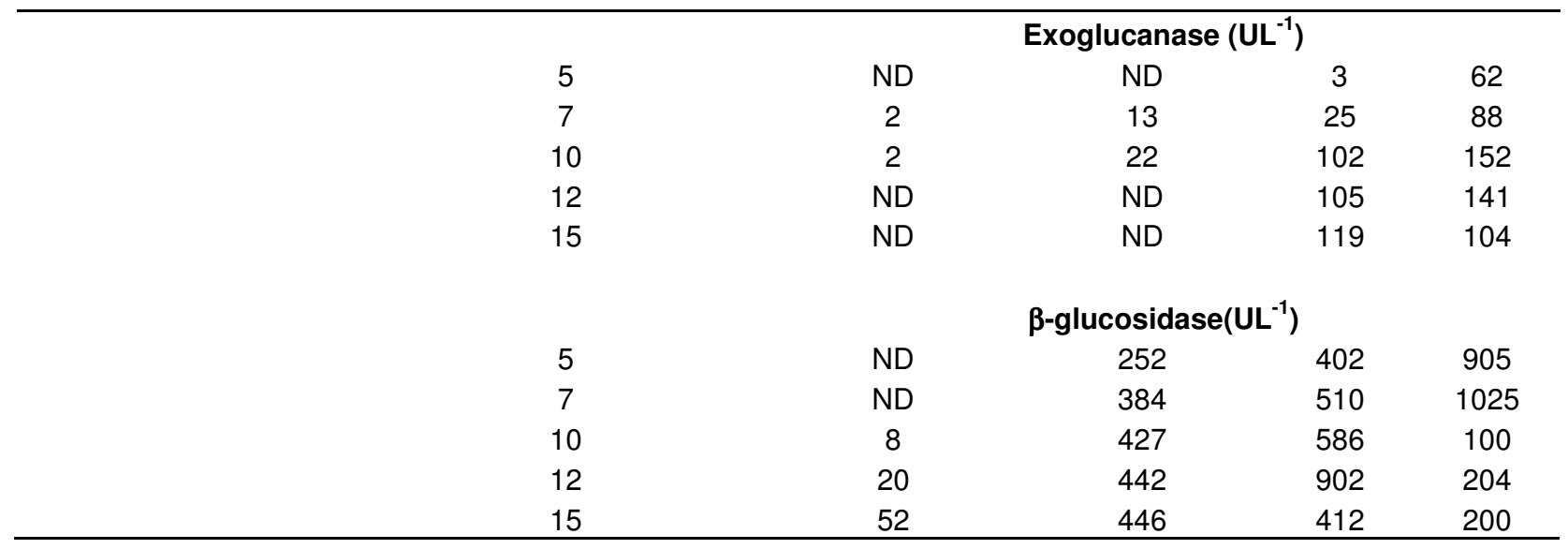

Table 3. Effect of incubation temperature on dry biomass and cellulolytic enzymes production by $P$. florida.

\begin{tabular}{ccccc}
\hline $\begin{array}{c}\text { Incubation } \\
\text { temperature }\left({ }^{\circ} \mathbf{C}\right)\end{array}$ & $\begin{array}{c}\text { Mycelia biomass dry } \\
\text { weight }\left(\mathbf{g l}^{-1}\right)\end{array}$ & \multicolumn{3}{c}{ Cellulases activity $\left(\right.$ IUL $\left.^{-1}\right)$} \\
\cline { 3 - 5 } & 2.8 & 142 & 15 & Endoglucanase \\
\hline 20 & 6.0 & 149 & 42 & 956 \\
25 & 5.2 & 260 & 62 & 1054 \\
30 & 3.2 & 460 & 106 & 963 \\
35 & 0.9 & 502 & 112 & 106 \\
40 & 0.8 & 12 & - & - \\
45 & & &
\end{tabular}

$25^{\circ} \mathrm{C}$ and lowest at $40^{\circ} \mathrm{C}$. Thus high temperature promotes production of cellulolytic enzyme but not biomass production. Phutela et al. (1996) showed temperature optima of $35 \pm 2{ }^{\circ} \mathrm{C}$ for cellulolytic/ hemicellulolytic enzymes production by Volvariella. However, $\beta$-glucosidase showed an optimum activity with incubation temperature of $30^{\circ} \mathrm{C}$ and was lowest at $40^{\circ} \mathrm{C}$. Since $\beta$-glucosidase is relatively more thermostable ( $\mathrm{Tm}$ $72^{\circ} \mathrm{C}$ ) as compared to endo- and exoglucanase, the lower activity of this enzyme at higher temperature cannot be attributed to its denaturation. The differential effect of temperature on the production of $\beta$-glucosidase indicates that its production might be regulated in a manner different from endoglucanase and exoglucanase. This finding corraborates the earlier results suggesting a separate control of $\beta$-glucosidase (Harchand and Singh, 2001).

\section{Effect of CMC level}

To test the effect of CMC level on cellulolytic enzyme production, three concentrations (1,2 and $3 \%$ ) of CMC were used in the production medium (Figure 1a). Production of all the three cellulolytic enzymes increased with increase in $\mathrm{CMC}$ concentration and was maximum at $3 \%$ level. However, no significant change in extracellular cellulase production by $P$. ostreatus with increasing concentrations of wheat straw (1 to $6 \%$ ) has been reported (Garzillo et al., 1994).

\section{Effect of initial pH}

To determine the optimum $\mathrm{pH}$ for production of cellulolytic enzymes, the fungus was grown at different initial $\mathrm{pH}$ ranging from 4.0 to 6.5 . The maximum production for endo- and exoglucanase was 5.0 and for $\beta$-glucosidase it was 4.5 (Figure 1b).

\section{Characterization of cellulases}

Enzymes produced from $P$. florida were characterized for their optimum $\mathrm{pH}$, temperature and thermostability. All the three cellulolytic activities of cellulases had a broad $\mathrm{pH}$ range with maximum activity at $\mathrm{pH}$ 4.4. Likewise the optimum temperature for all the three activities was found to be $45^{\circ} \mathrm{C}$. For determining thermostability of cellulolytic enzymes, the crude enzyme preparation was exposed to 


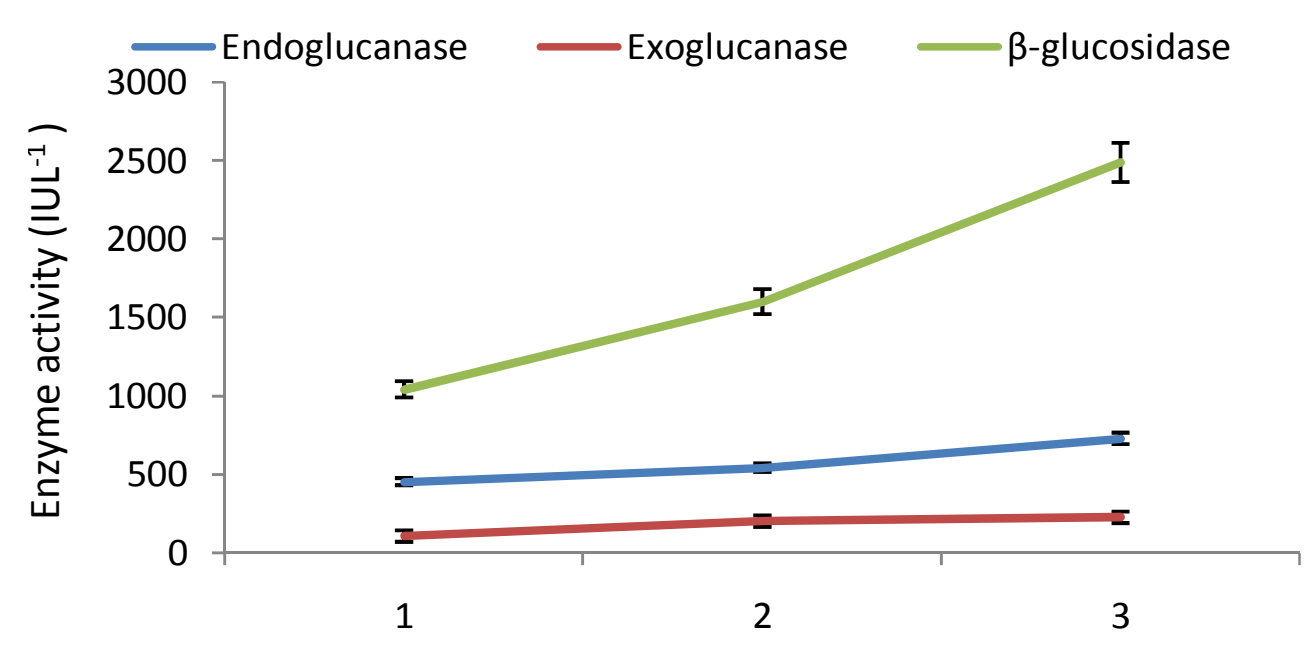
a
CMC concentration (\%)

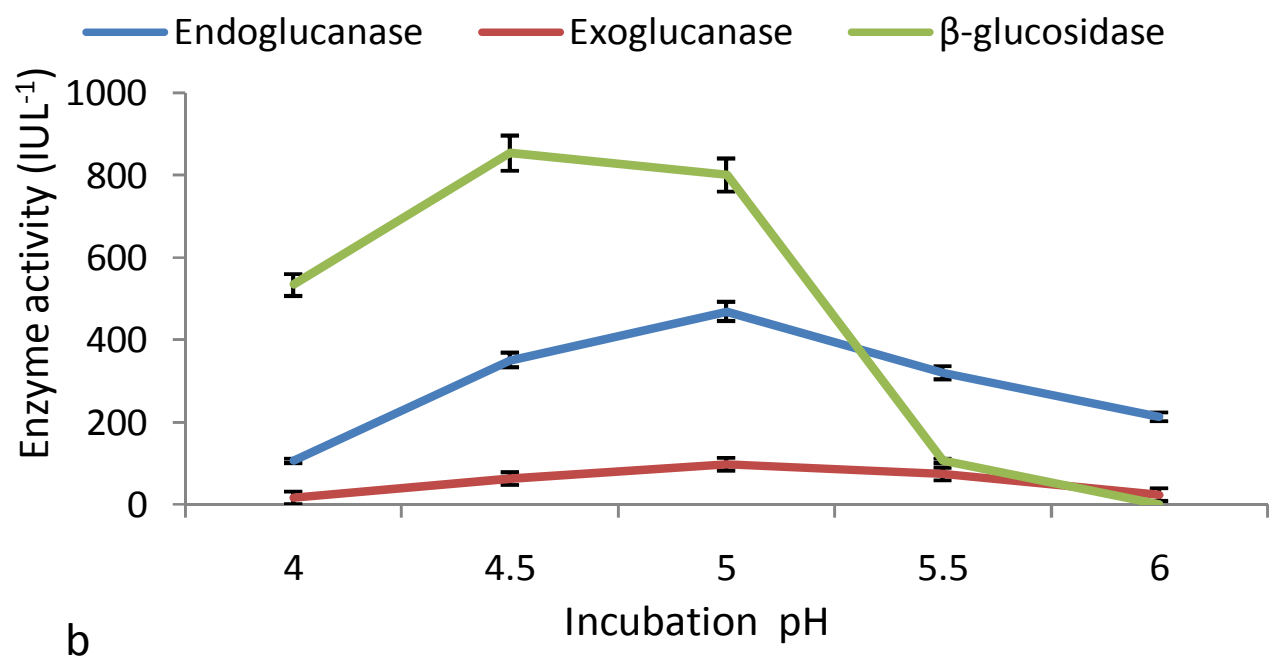

Figure 1. Effect of $\mathrm{CMC}$ concentration (a) and incubation $\mathrm{pH}$ (b) on cellulolytic enzymes production (IUL ${ }^{-1} \pm \mathrm{SE}$ ) by $P$. florida in Czapek medium.

different temperatures ranging from 35 to $75^{\circ} \mathrm{C}$ for $15 \mathrm{~min}$ and then cooled in an ice-cold water. The residual activity was measured under standard assay conditions. Tm, the temperature at which the enzyme activity was reduced to $50 \%$ of the original activity was determined by plotting residual activity Vs exposure temperature. Of all these enzymes, $\beta$-glucosidase was the most thermostable followed by endoglucanase and exoglucanase with $\mathrm{Tm}$ of 72,66 and $58^{\circ} \mathrm{C}$, respectively. From these results, it may be concluded that $P$. florida can be exploited for the production of cellulolytic enzymes or biomass as the conditions warrant, by altering culture conditions. The differential response for production of $\beta$-glucosidase and endo- and exoglucanase towards the different culture conditions indicating separate regulatory mechanisms.

\section{REFERENCES}

Albores S, Pianzzola MJ, Soubes M, Cerdeiras MP (2006). Biodegradation of agroindustrial wastes by Pleurotus spp for its use as ruminal feed, Electronic J. Biotechnol. [online] 9 no 3 Available from http:/ www. ejbiotechnology.info/content/vol 9/issue3/full2/2.pdf ISSN 0717-3458.

Baig MMV (2005). Cellulolytic enzymes of Trichoderma lignorum produced on banana agro-waste: Optimization of culture medium and conditions. J. Sci. Ind. Res., 57: 57-60.

Garzillo AMV, Paolo SD, Ruzzi M, Buonocore V (1994). Hydrolytic properties of extra cellular cellulases from Pleueotus ostreatus. Appl. Microbiol. Biotechnol., 42: 476-481. 
Harchand RK, Singh S (2001). Induction of cellulases in Streptomyces albaduncus by different substrates. Indian J. Microbiol., 41: 45-49.

Mandels M, Andreotti REP, Roche C (1976). Measurement of saccharifying cellulose. Biotechnol. Bioeng. Symp., 6: 21-33.

Mandels M, Stenberg D (1976). Recent advances in cellulase technology. J. Ferment. Technol., 54: 267-286.

Masaphy S, Lavanon D (1992). The effect of lignocellulose on lignocellulolytic activity of Pleurotus pulmonarius in submerged culture. Appl. Microbiol. Biotechnol., 36: 828-832.

Miller GL (1959). Use of Dinitrosalicylic acid reagents for determination of reducing sugars. Anal. Chem., 31: 426-429.

Narsimha G, Sridevi A, Buddolla V, Subhosh Chander M (2006). Nutrient Effect of production of cellulolytic enzymes by Aspergillus niger. Afr. J. Biotechnol., 5: 472-476.

Phutela RP, Bhadauria A, Kapoor S (1996) Screening of Chinese Mushroom (Volvariella spp) strains for cellulases and xylanases production. Indian J. Microbiol., 36: 125-128.
Platt MW, Hader Y, Chet I (1984). Fungal activities involved in lignocellulose degradation by Pleurotus. Appl. Microbiol. Biotechnol., 20: 150-154.

Salmones D, Mata G, Waliszewski KN (2005). Comparative culturing of Pleurotus spp on coffee pulp and wheat straw: biomass production and substrate biodegradation. Biores. Technol., 96: 537-544.

Tan YH, Wahab MN (1997). Extracellular enzyme production during anamorphic growth in the edible mushroom, Pleurotus sajar-caju. World Microbiol. Biotechnol., 13: 613-617.

Zhang R, Li X, Fadel JG (2002). Oyster mushroom cultivation with rice and wheat straw. Biores. Technol., 82: 277-284. 